\title{
Measured depth of subcutaneous tissue on posterolateral arm of aeroallergen immunotherapy patients
}

\author{
Laura Kim', Ryan Potts ${ }^{2}$, Clark Eeuwes ${ }^{3}$, Arunmozhi Dominic ${ }^{3}$, Immaculate Nevis ${ }^{4}$, Harold L Kim ${ }^{3,4^{*}}$ \\ From Canadian Society of Allergy and Clinical Immunology Annual Scientific Meeting 2012 \\ Calgary, Canada. 11-14 October 2012
}

\section{Background}

Subcutaneous immunotherapy (SIT) injections for aeroallergens are often utilized in patients. SIT should be injected into the subcutaneous space in the mid-posterolateral upper arm. If the injections are given intramuscularly (IM), there may be an increased risk of anaphylaxis. In our allergy clinic, SIT is given with BD Safety Glide ${ }^{\mathrm{TM}}$ Allergy syringes with needle length $13 \mathrm{~mm}$. There is a risk of the SIT being injected IM if patients have a skin to muscle depth (STMD) less than $13 \mathrm{~mm}$.

\section{Methods}

Charts were reviewed in an allergy clinic for patients on SIT where an ultrasound of the left posterolateral arm was done to measure STMD. Baseline characteristics of the two groups of patients with STMD greater than, and less than or equal to $13 \mathrm{~mm}$ were compared. The proportions of patients with STMD greater than $4 \mathrm{~mm}, 6 \mathrm{~mm}, 8 \mathrm{~mm}$, and $10 \mathrm{~mm}$ were calculated. Multivariable logistic regression was performed with age, sex, BMI and race.

\section{Results}

Ultrasounds had been completed on 186 patients on SIT. There were 149 (80\%) with STMD less than 13mm. Baseline characteristics including age, sex and BMI differed among the two groups $(p<0.05)$. Based on the logistic regression analysis, BMI was significantly associated with STMD. There were 168 (90\%) patients with more than $4 \mathrm{~mm}$ STMD.

\section{Conclusions}

With standard allergy syringes, most patients on SIT are at risk of receiving the injections IM. A needle length of $4 \mathrm{~mm}$ would significantly decrease the risk of SIT being given IM.

\section{Author details}

${ }^{1}$ McGill University, Montréal, Québec, Canada. ${ }^{2}$ University of Waterloo, Waterloo, Ontario, Canada. 3University of Western Ontario, London, Ontario, Canada. ${ }^{4}$ McMaster University, Hamilton, Ontario, Canada.

Published: 2 November 2012

doi:10.1186/1710-1492-8-S1-A7

Cite this article as: Kim et al: Measured depth of subcutaneous tissue on posterolateral arm of aeroallergen immunotherapy patients. Allergy, Asthma \& Clinical Immunology 2012 8(Suppl 1):A7.
Submit your next manuscript to BioMed Central and take full advantage of:

- Convenient online submission

- Thorough peer review

- No space constraints or color figure charges

- Immediate publication on acceptance

- Inclusion in PubMed, CAS, Scopus and Google Scholar

- Research which is freely available for redistribution 